\title{
Hřišná exotika A. V. Nováka Literární obraz cesty do Asie v letech 1926-1927
}

\author{
Mgr. Jan Šejbl, DiS. \\ Národní muzeum \\ $\triangle$ jan.sejbl@nm.cz
}

Předložená práce vznikla za finanční podpory Ministerstva kultury v rámci institucionálního financování dlouhodobého koncepčního rozvoje výzkumné organizace Národni muzeum (DKRVO 2019-2023/19.III.c, 00023272)

Orientalia Antiqua Nova XXI ISBN 978-80-261-1039-2

Západočeská univerzita v PIzni, 2021 https://doi.org/10.24132/ZCU.2021.10392-120-144 


\section{Abstract}

\section{Sinful Exotics of A. V. Novák}

\section{Literary image of a journey to Asie in 1926-1927}

Traveller and writer Archibald Václav Novák (1895-1979) rose to fame in the 1920s as the author of popular novels and short stories inspired by a stay in Tahiti and the United States of America from 1919 to 1921. Sucesess of books and lectures allowed Novák to undertake another long journey. From October 1926 to April 1926 A. V. Novák visited Sri Lanka, India, Myanmar, Malaya, Singapore, Sumatra, Vietnam, Cambodia, China and Japan. After returning home, Novák organized public lectures and published new novels and short stores inspored by the places he visited and the people he met. He also wrote a four-volume travelogue based on his travel diary. On his journey, Novák took not only still photographs, but short movies as well. After the communists took power in Czechoslovakia in 1948, Novák was purged from public life. No longer heralded as either a traveller or a writer, he was virtually consigned to oblivion. It was not until after 2000 that a study of the phenomenon of Czechoslovak emigration to Tahiti kindled renewed interest in him. In 2010, some of Novák's previously unknown photographs were discovered and donated to the Náprstek Museum's photographic collection, which is a part of the National Museum in Prague. Movies, diaries and the most of negatives by A. V. Novák have not been preserved, but there is a large number of glass slides used as an accompaniment of lectures. Photographic collection and books by A. V. Novák offer a valuable source of information about the non-Europen countries in 1920s and the ways, how they were presented to public in Czechoslovakia. 
Spisovatel a cestovatel Archibald Václav Novák (1895-1979) se proslavil ve dvacátých letech 20. století především jako autor populárních románů a povídek zasazených do Polynésie. Ve své tvorbě se však věnoval také asijským zemím, které navštívil během poznávací cesty v letech 1926-1927. Po roce 1948 byl jako člen Československé strany národně socialistické a soukromý podnikatel vyloučen z veřejného dění. Pro populární zaměření své tvorby byl také označován jako autor brakové literatury. Jako spisovatel i jako cestovatel tak byl dlouhou dobu opomijen.

Teprve po roce 2000 se mu dostalo nové pozornosti v souvislosti s výzkumem českého vystěhovalectví do francouzské Oceánie. V roce 2000 vyšel článek o osudech české kolonie na Tahiti, ${ }^{1}$ který se opírá o četné archivní prameny především z fondu Národního archivu. O čtyři roky později Česká televize odvysílala dvanáctidílný dokumentární pořad Příběhy z jižních moři ${ }^{2}$ a v roce 2005 vyšla monografie Vladimíra Ustohala Češi na Tahiti a Markézách. ${ }^{3}$

Osobností A. V. Nováka se dlouhodobě zabývá také autor tohoto přispěvku. $V$ roce 2010 se podařilo objevit dosud neznámou část Novákovy fotografické pozůstalosti, která se o rok později darem stala součástí etnografické fotosbírky Náprstkova muzea asijských, afrických a amerických kultur, které je organizační složkou Národního muzea v Praze. Z rozsáhlého souboru 1398 snímků tvoři nadpoloviční většinu (52\%) snímky asijské provenience. $V$ dalším textu se zaměříme právě na Novákovu asijskou cestu a způsob, jakým ji využil v přednáškové a literární činnosti.

Archibald Václav Novák, vlastním jménem Václav Novák, se narodil 28. dubna 1895 v jihočeských Vodňanech. Byl nejmladším

${ }^{1}$ Křestan 2000.

${ }^{2}$ Česká televize 2004.

${ }^{3}$ Ustohal 2005. 
ze čtyř synů soudního úředníka. Novákovo dětství poznamenala předčasná smrt otce, která rodinu přivedla do materiální nouze. Václavu Novákovi v té době byly čtyři roky. $O$ rok později při dětské hře navíc přišel o levé oko. Ve Vodňanech se Václav Novák vyučil zedníkem. Krátce po získání výučního listu v červnu 1912 odjel do Prahy, kde studoval na střední průmyslové škole a vydělával si prací ve stavebnictví.

Myšlenkou na cestu do zahraničí se začal Novák poprvé vážně zabývat $v$ období první světové války. V roce 1916 se oženil s bankovní úrednicí Marií Hohausovou. Stále se zhoršující situace $v$ zemi způsobená válkou vedla mladé manžele $\mathrm{k}$ úvahám o svobodném životě v tropické prírodě. Pod dojmem knihy Henri Bernardin de Saint-Pierra Indická chatrč byla prvním cílem těchto úvah Indie. ${ }^{4}$ Volba však nakonec padla na Oceánii, především díky zprávám o činnosti Milana Rastislava Štefánika, který zde $v$ roce 1910 vybudoval astronomickou observatoř.

Novák plánoval, že po skončení války Štefánika osloví s nabídkou spolupráce a odjede s ním na Tahiti. Po tragické smrti Štefánika v květnu 1919 se Novák rozhodl, že se alespoň vydá po jeho stopách a zjistí, v jakém stavu je observatoř na Tahiti a zda je možné ji obnovit. I s manželkou opustil vlast v září 1920. Na Tahiti se chtěli usadit natrvalo. Prostředky na další cestu Novák získával přednáškovou činností pro české a slovenské krajany $\checkmark$ USA, které seznamoval $s$ průběhem prvni světové války a se vznikem Československa. Psal také články do krajanských novin. Pobyt ve Spojených státech amerických se nakonec protáhl na celý rok, během kterého se manželům Novákovým narodil syn Václav. $V$ cestě na Tahiti pokračovala celá rodina až v záři 1920.

${ }^{4}$ Novák 1933, 269. 
Pobyt na Tahiti nevyšel zcela podle představ. Ukázalo se, že hvězdárna je opuštěná a bez vybavení, které Štefánik odvezl při odjezdu z Tahiti s sebou. Jeji obnovení tak neprípadalo v úvahu. Také možnosti usadit se na Tahiti natrvalo nebyly tak dobré, jak si mladí manželé představovali. Nebylo možné získat pozemek pro vlastní hospodářství. Novák navštívil také blízký ostrov Moorea a Podvětrné ostrovy, ale ani tam nebyla situace lepší. Po třech měsících se Novákovi rozhodli k návratu do USA. Zde Novák uspořádal nové přednáškové turné pro krajany, doplněné o zkušenosti z návštěvy Oceánie. Do Československa se Novákovi vrátili až v červnu 1921.

Po návratu do vlasti využil Václav Novák své zkušenosti s přednáškami a přednášel o své cestě do USA a na Tahiti. Ke jménu si připojil umělecké jméno „Archibald“. Nejčastěji jej uváděl ve zkráceném tvaru „A. V. Novák“. Věnoval se také literární činnosti. Ve vlastním nekoncesovaném "Nakladatelství knih cestovatele A. V. Nováka“ od roku 1922 vydával povídkové sbírky a romány, zasazené do míst, která při své cestě navštivil. Největší úspěch zaznamenala povídková sbírka Povídky z Tahiti, ostrovů hřišné lásky, která se dočkala celkem sedmi vydání.

Novákovy knihy i přednášky vzbudily značný zájem veřejnosti, ale vyvolaly i určité kontroverze. Kritici v čele s cestovatelem a diplomatem Janem Havlasou Novákovi vytýkali, že čtenářưm predkládá nepřesné informace a že se nepřimo podílí na podpoře vystěhovalectví Čechů do Francouzské Oceánie. Některé Novákovy knihy se také dočkaly označení mravně závadného braku, především po roce 1939 a $1948 .^{5}$

Už při cestě do USA a na Tahiti si Novák se zájmem všímal asijských prvků, se kterými se zde setkal. V San Francisku navštivil

$\overline{5}$ Janáček 2004, 121. 
čínskou čtvrt a také japonskou čajovnu a park v Golden Gate Parku. V Oceánii jej pak zaujali čínští přistěhovalci, kteří se zde uplatnili především jako obchodníci. Jejich vliv byl zvlášt silný na ostrově Raiatea, který Novák označil jako „zpoloviny čínský“. 6

Novák ve svých knihách vnímá vliv čínských a evropských přistěhovalců v Oceánii negativně a viní jej $z$ úpadku původního obyvatelstva a jeho kultury. Pozastavuje se také nad zájmem, kterému se Číňané těšili u tahitských dívek. Ty se s nimi údajně často a rády intimně stýkaly, většinou motivovány hmotným ziskem. $V$ povídkové sbírce Tropické noci věnoval Novák povídku Lin-tanova a Fon-šajova společná manželka líčení milostných dobrodružství dvou čínských přistěhovalců, kteří vlastnili malý obchůdek u vesnice Faa na Tahiti.

Úspěch přednášek a knih umožnil Novákovi Asii přimo navštívit. Na rozdil od cesty do USA a na Tahiti nejel do Asie hledat nový domov, ale nová témata pro svou tvorbu. Díky podrobnému popisu cesty, který Novák publikoval ve čtyřech dílech cestopisu s názvy Cejlonem a Indií, Malajskem na Sumatru, $V$ zemi žlutých a Japonské jaro, můžeme rekonstruovat přesný itinerář Novákovy cesty i její přesný průběh.

Z Prahy odjel A. V. Novák 27. ríjna 1926 vlakem přes Pařiž. 29. řijna odplul z francouzského prístavu Marseille na palubě lodi Amazon na ostrov Šrí Lanka. Cesta se zastávkami v Port Saidu, Džibuti a Adenu trvala celkem 18 dní. Výchozím bodem se zde stalo Colombo, odkud Novák podnikl jednak cestu na jih podél pobřeží až do Hikkudavy, jednak do vnitrozemí k památnému městu Kandy. Celkem strávil na ostrově dva týdny. 30. listopadu 1926 opustil naposledy Colombo a vydal se vlakem na sever k prístavu Talaimannar, odkud se lodí přeplavil na indický subkontinent.

$\overline{{ }^{6} \text { Novák 1931c, } 182 .}$ 


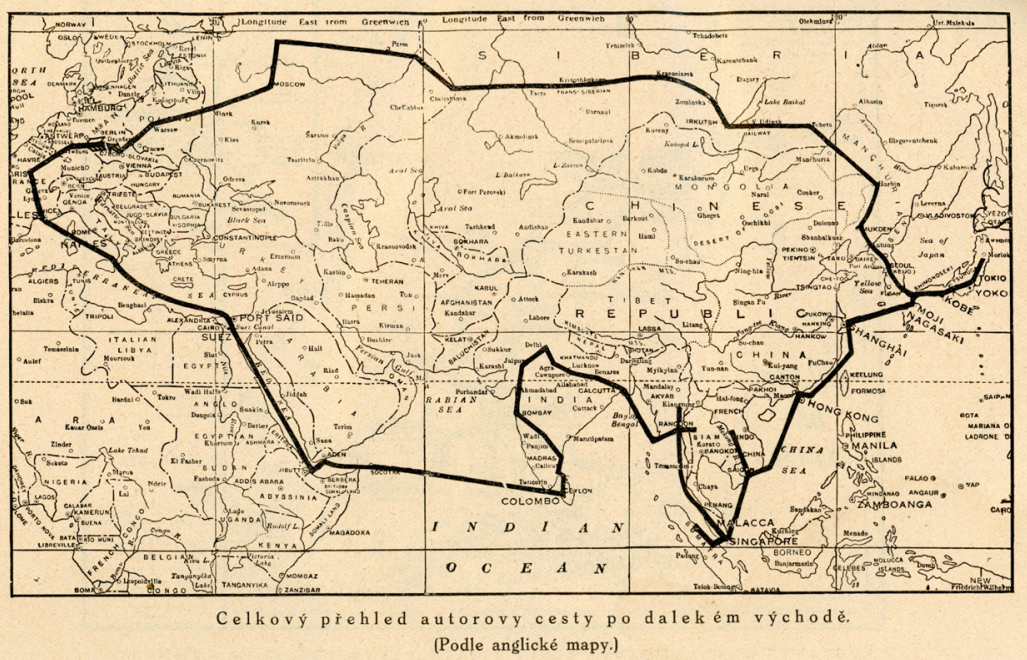

Přiloha 1. Mapa asijské cesty A. V. Nováka v letech 1926-1927. Zdroj: Novák, A. V. 1932. V zemi žlutých. Horní Černošice: Nakladatelství knih cestovatele A. V. Nováka.

Po Indii cestoval dále vlakem. Během tři dnů s krátkými zastávkami ve městech Madurai a Čennai docestoval Novák do Bombaje. Zde se setkal s krajanem Zdenkem Lvovským, který jej seznámil s konzulem Augustinem Lafarem a obchodním atašé panem Strakatým. Díky tomu měl Novák během třídenního pobytu možnost dobře poznat město i jeho blízké okolí.

8. prosince opustil A. V. Novák Bombaj a vydal se na další cestu. Vlakem odjel nejprve do Džajpuru, kde si během jednoho dne $v$ doprovodu domorodého průvodce prohlédl město i blízké historické město a pevnost Amber. Z Džajpuru pokračoval Novák do Dillí. Na prohlídku města si vyhradil také pouhý den, ještě ten samý večer odjel do Ágry. Zde byla jeho hlavním zájmem hrobka Tádž Mahal. Kvůli jízdnímu řádu vlaků si Novák pobyt 


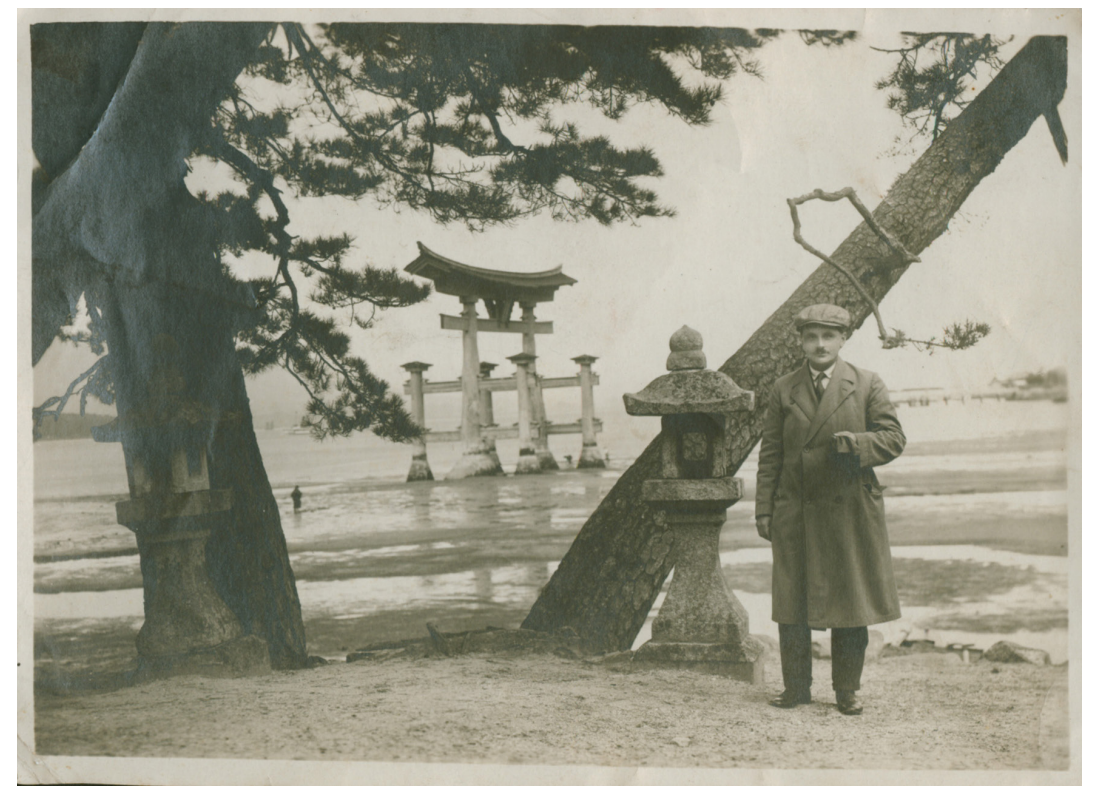

Příloha 2. 17-18 - A. V. Novák u svatyně Icukušima, duben 1927. Zdroj: Národní muzeum - Náprstkovo muzeum, Archiv Náprstkova muzea, fond Novák Archibald Václav, karton 17, inv .č. 18.

v Ágře o jeden den prodloužil, a navštívil ještě Akbarovu hrobku v Sikandře a historické město Fatehpur Sikrí. Poslední etapou Novákovy cesty po Indii byla jízda vlakem do Kalkaty se zastávkami ve významných poutních místech Váránásí a Bódhgaja. V Kalkatě se Novák nalodil na britskou lod' Endavana, která měla namíreno k Malajskému poloostrovu.

První zastávkou na plavbě byl přistav Rangún v dnešním Myanmaru. Lod' zde kvůli nakládce zboží stála celkem tři dny, a tak měl A. V. Novák dost času nejen k prohlídce města a jeho památek, ale také ke dvěma výletům vlakem na venkov do Dameinu 


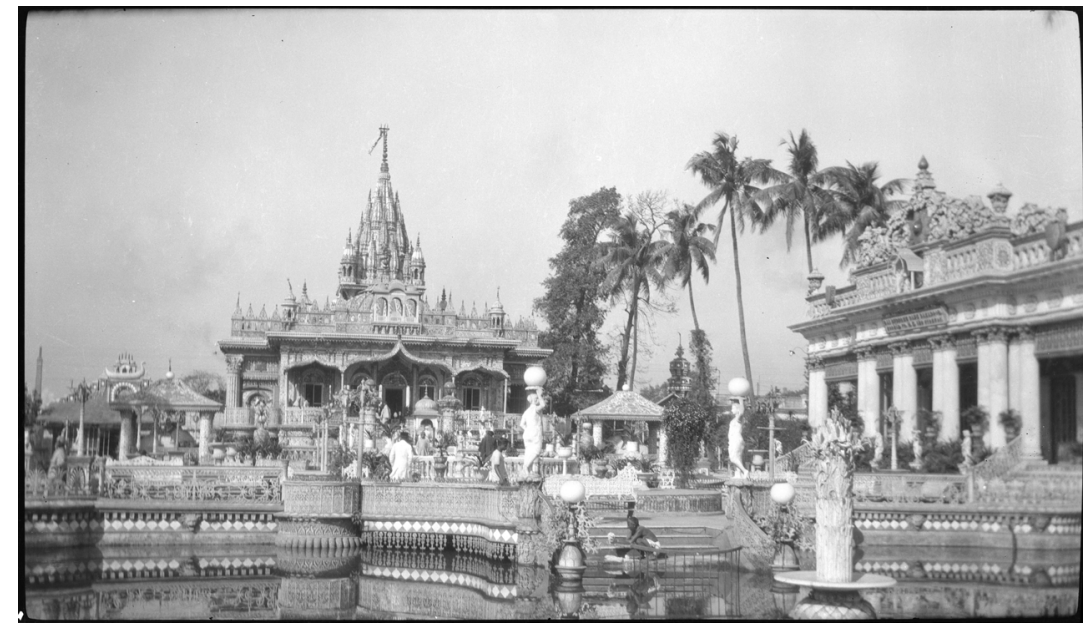

Přiloha 3. As I 8842 - Džinistický chrám v Kalkatě. Jeden z dvanácti dochovaných autorských negativů. Zdroj: Národní muzeum - Náprstkovo muzeum, Etnografická fotosbírka, inv. č. As II 2845.

a Inseinu. Dva dny po odplutí z Rangúnu oslavil A. V. Novák na palubě lodi Vánoce. Již 26. prosince lod' zakotvila v prístavu Georgetown na malajském ostrově Penang. Ten se měl stát výchozím bodem pro další Novákovu cestu po Malajsku. Nováka na ní doprovázel skotský inženýr Whitaker, který pracoval pro indické dráhy a jel do Malajska na dovolenou.

Pobyt na ostrově Penang se nakonec protáhl na čtyři dny, především kvůli deštivému počasí. Novák původně plánoval cestovat na jih po pevnině železnicí, ale zprávy o komplikacích způsobených záplavami jej přiměly využít čínské lodi až do přístavu Port Klang. Novák a jeho skotský společník sem dorazili právě 31. prosince 1926. Nový rok 1927 věnovali návštěvě Kuala Selangoru. Další den se Novák vypravil navštívit příslušníky etnika Jakun, kteří 
patří k původním obyvatelům Malajského poloostrova. Při obou cestách Novák využil služeb nájemního automobilu.

Z Klangu se Novák a jeho společník přemístili do nedaleké metropole Kuala Lumpuru. Zatímco inženýr Whitaker se zde rozhodl zůstat delší dobu, Novák zde pobyl pouze dva dny a urychleně odjel. Vedle komplikací s výběrem vhodného hotelu přitom sehrála roli i neochota přizpůsobovat se při plánování cesty zájmům svého společníka. Novák odjel vlakem na jih do Sembilanu a dále do sultanátu Johor. $V$ Johore Bahru získal ubytování prímo v sultánově paláci, ale audienci se mu získat nepodařilo. Cestu po Malajském poloostrově Novák zakončil v prístavu Singapur.

Ze Singapuru podnikl Novák cestu na ostrov Sumatra. Na palubě holandské lodi Melchior Traub odplul do přistavu Belawan a odtud vlakem do města Medan. Odtud se autobusem vydal do vnitrozemí do Berastagi, kde díky př́ijemnějšímu klimatu fungovalo horské letovisko pro holandské i anglické úředníky z kolonií. Pět dní zde strávil i $A$. V. Novák. Berastagi se pro něj stalo výchozím bodem pro cesty $\mathrm{k}$ jezeru Toba a do okolních vesnic Bataků, původních obyvatel Sumatry. Jejich život jej zajímal především. Před odjezdem vystoupil také na vrchol sopky Sibajak. Před odjezdem ze Sumatry podnikl ještě z Medanu krátkou cestu na sever do města Tanjung Pura.

20. ledna opustil Novák na palubě holandské lodi Pancius Sumatru a o dva dny později se vrátil do Singapuru. Zde zvažoval směr dalši cesty. Lákala jej návštěva Bornea, Nové Guineje či dnešního Thajska, ale nakonec se vydal do dnešního Vietnamu a Kambodže. 24. ledna 1926 se nalodil na francouzskou lod' Angkor, miŕící do přistavu Saigonu (dnes Ho Či Minovo město). Na palubě lodi se setkal se svým společníkem z cesty po Malajském poloostrově, skotským inženýrem Whitakrem. Seznámil se také s francouzskými koloniálními úředníky, kteří cestovali 
na svá nová působiště nebo se vraceli z dovolené. Navázané kontakty mu prokázaly cenné služby během pěti dní, strávených v Saigonu. Poznával město i jeho okolí, v nedalekém Cholonu se setkal také s krajanem. Pan Macháček, který zde vedl pivovar, Nováka pohostinně přijal a nabídl mu dokonce výlet automobilem na plantáže a do pralesa k příslušníkům etnika Man (Moï).

Ze Saigonu se Novák vydal autobusem na sever do Kambodže. Strávil zde deset dní, většinu z nich v hlavním městě Phnom Penhu, kde se věnoval především poznávání města a návštěvám památek. Najatým automobilem se vydal také na venkov, do vesnice Koti. Jeho hlavním zájmem však byla návštěva chrámového komplexu Angkor Vat. To znamenalo dalších 300 km autobusem na sever do města Siem Reap v blízkosti Angkor Vatu. Jeho prohlídce věnoval celé tři dny. Monumentální stavby na něj udělaly hluboký dojem. Po návratu do Phnom Penhu se Novák vrátil najatým automobilem zpět do Saigonu. Před odjezdem ještě jednou navštívil krajana Macháčka, a při té př́ležitosti si prohlédl jeho sbírku starožitností. Rozloučil se také se skotským inženýrem Whitakrem, který zůstal v Saigonu a plánoval návrat do Indie.

13. února 1926 se Novák na palubě francouzské lodi Porthos vydal na cestu do Číny. Ta jej velice lákala. Měl již možnost setkat se s čínským obyvatelstvem v Oceánii i v zemích jihovýchodní Asie, plánoval tedy důkladně procestovat i samotnou Čínu. Pro delší návštěvu však nebyla vhodná doba kvůli politickým nepokojům a ozbrojeným střetům mezi Kuomintangem a komunistickou stranou. První zastávkou na plavbě byl přístav Hongkong, který Novákovi připomínal ze všeho nejvíce americké město. O čtyři dny později se Novák vylodil v Šanghaji. Ve městě byla právě stávka, československý konzulát byl opuštěný a z předměstí bylo slyšet střelbu. Původní plány vydat se proti proudu řeky Jang-c'-tiang do vnitrozemí vzaly za své. Po třech dnech pobytu 
Novák opustil Šanghaj na palubě japonské lodi Nagasaki Maru, plující do Japonska.

V Japonsku strávil A. V. Novák téměř dva měsíce, pobýval zde od 24. února až do 17. dubna 1927. Lod' opustil v Nagasaki, odkud se nejprve vypravil k termálním pramenům na poloostrov Šimbara. Po návratu se vydal pres Šimonoseki a Hirošimu na ostrov Icukušima, kde navštívil známou svatyni. Přes týden pobýval $\checkmark$ Kóbe, kde se setkal s japonskými praáteli československých legionářŭ, kteři se přes Japonsko po první světové válce vraceli ze Sibiře do vlasti. Při pobytu v Kóbe navštívil také Kjóto, Ósaku, Naru či Takarazuku.

Z Kóbe se Novák vydal do Tokia kolem jezera Biwa a poté po pobřeži přes letovisko Atami. V Tokiu byl také týden. Setkal se zde $s$ několika Čechy žijícími v Japonsku - velvyslancem Josefem Švagrovským, tajemníkem Janem Fierlingerem, ing. Švagrem, architektem Bedřichem Feuersteinem a také s panem Oplatkou, který byl zaměstnán ve fotografickém závodě. Tajemník Fierlinger Nováka provedl po zajímavostech a památkách Tokia. Ve městě byly stále patrné stopy velkého zemětřesení z 1 . zárí 1922. Novák navštívil i blízký prístav Jokohama, známou sochu velkého Buddhy v Kamakuře i ostrov Enošima. Vydal se také do města Nikkó, kde navštívil svatyni Tóšógú. Na konci března se Novák přes Gotembu, Šizouku, Nagoju a Kjóto vrátil zpět do Kóbe. Podruhé zde zůstal sedmnáct dní. V nedalekém Kjótu navštívil taneční vystoupení Mijako odori, ale především vyřizoval potřebné formality pro zpáteční cestu. Rozhodl se totiž vrátit přes Sovětský svaz transsibiřskou magistrálou.

16. dubna 1927 se Novák rozloučil se svými japonskými přáteli v Kóbe a vydal se přes Hirošimu do prístavu Šimonoseki, odkud se další den přeplavil do korejského přistavu Pusan. Následovala cesta vlakem na sever přes Šen Jang do Charbinu, odkud 
odjižděly spoje do Evropy. Cesta vlakem z čínského Charbinu do Moskvy trvala sedm dní. Poslední etapou Novákovy cesty byla jízda vlakem z Moskvy přes Varšavu do vlasti.

Během celé cesty si Novák vedl podrobné zápisky, fotografoval i filmoval. Kromě fotografického aparátu na svitkový film 9×14 $\mathrm{cm}$ měl s sebou také filmovou kameru značky Ica, poháněnou pérovým strojkem. $Z$ vydaných cestopisů vyplývá, že během cesty si vedl deníkové záznamy a psal i první povídky inspirované místy, která navštívil. Po návratu do vlasti si také nechal zhotovit podle vlastních fotografii i nakoupených pohlednic a ilustrací několik sad diapozitivů jako doprovod pro přednášky.

Rukopisy deníků se bohužel nedochovaly, ale do určité míry je mohou nahradit publikované cestopisy, které z nich evidentně vycházejí. Zkáze podlehly také kinematografické filmy, které A. V. Novák na své cestě natáčel. V cestopisech se často zmiňuje, co bylo objektem jeho filmové kamery. Namátkou můžeme uvést břišní tanec ve čtvrti nevěstinců v Džibuti, krajinu na pobřeží a zaklínače hadů na Srí Lance, život Bataků ve vesnici u jezera Toba na Sumatře či chrámové tanečnice u Angkor Vatu.

Pouhý zlomek se dochoval také z nepochybně rozsáhlého souboru fotografických negativů. Těch máme dnes $\mathrm{k}$ dispozici pouze dvanáct. Jedná se o snímky z různých míst asijské cesty: tři byly pořízeny při zastávce $v$ Adenu $v$ listopadu 1926, jeden snímek je ze Srí Lanky a jeden z Indie. Dva snímky pocházejí ze zastávky v Myanmaru při plavbě z Indie do Malajsie v prosinci 1926, dva negativy byly pořizeny v Kambodži v únoru 1927. U tří snímků není možné určit místo, kde byly pořizeny.

\footnotetext{
${ }^{7}$ Národní muzeum - Náprstkovo muzeum, etnografická fotosbírka, inv. č. As | 8835-As I 8846.
} 
Největši část dochované fotografické pozůstalosti A. V. Nováka tvoři diapozitivy $k$ přednáškám a pracovní negativy, určené $\mathrm{k}$ jejich výrobě. Výrobu a kolorování diapozitivư pro přednášky zajištovaly specializované firmy. Pokud měla být předlohou papírová pohlednice, fotografie či ilustrace, pořizovala se nejprve fotografie předlohy na skleněný negativ, ze kterého se potom dalším přefotografováním získal výsledný černobílý diapozitiv, který se ručně koloroval.

Ve fotografické pozůstalosti A. V. Nováka v Náprstkově muzeu se dochovaly celkem tři soubory diapozitivů z Novákovy asijské cesty. Soubor snímků k přednášce o Malajsii a Sumatře obsahuje 147 diapozitivů a 135 pracovních negativů. Soubor snímků k přednášce o Myanmaru, Vietnamu, Kambodži a o návratu přes Sibiř obsahuje 116 diapozitivů a 108 pracovních negativů. Nejúplnější je soubor snímků $k$ přednášce o Číně a Japonsku, který obsahuje 155 diapozitivů a 58 pracovních negativů. Naproti tomu zcela chybí diapozitivy ze Srí Lanky a Indie.

Jak už napovídá rozdělení dochovaných diapozitivů i dobové inzeráty, Novák nepřednášel o celé své cestě, ale rozdělil ji na jednotlivé části podle navštivených oblastí. Kromě „světelných obrazů“, jak bylo v té době promítání diapozitivů označováno, promital také kinematografické filmy a mluvený komentář doplňoval ukázkami hudby. Napřiklad přednáška s názvem Sumatra (pod žhavým sluncem rovníku), kterou přednesl pro Klub přátel Orientu 8. řijna 1932 ve fyzikálním sále pražské techniky, byla doprovázena „světel. obrazy, filmem a originální malajskou hudbou“.8 Také přednáška o Japonsku byla doprovázena "150 nádhernými světelnými obrazy života japonského lidu ve městě $i$ na venkově a všech krás Japonska a kromě toho autorovými i japonskými filmy: 1 . Z cest A. V. Nováka po Japonsku.

${ }^{8}$ Národní politika, č. 44, 13. 2. 1932. 


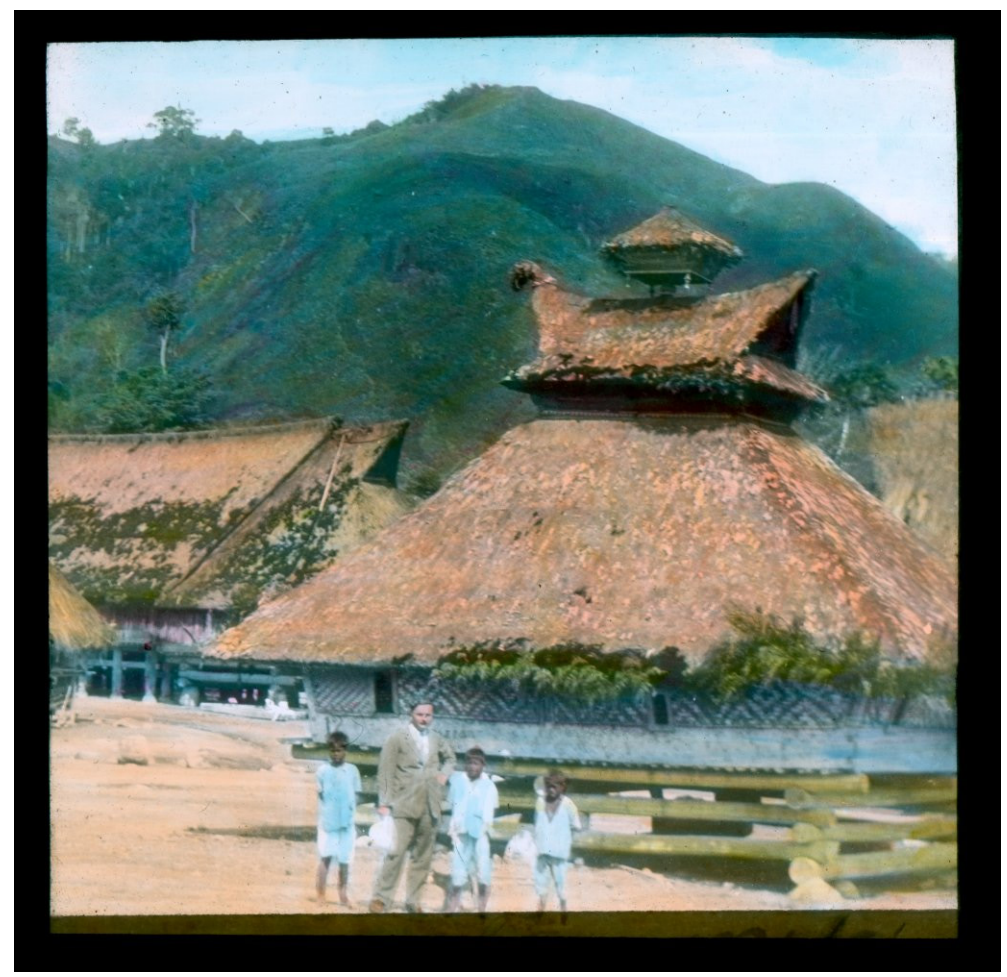

Př́loha 4. As II 2845 - A. V. Novák s batackými dětmi ve vesnici. Kolorovaný diapozitiv k přednášce o Sumatře. Zdroj: Národní muzeum - Náprstkovo muzeum, Etnografická fotosbírka, inv. č. As II 2845

2. Miadžima, nejkrásnější místo Japonska. 3. V Tokiu, když kvetou sakury". 9

Podobné rozdělení použil $A$. V. Novák také u svých cestopisů, ve kterých publikoval informace o své asijské cestě. V prvním

\footnotetext{
${ }^{9}$ Reprodukce dobového plakátu na diapozitivu, Národní muzeum - Náprstkovo muzeum, etnografická fotosbírka, inv. č. As II 2968.
} 
díle Cejlonem a Indií (1931) popsal cestu z Prahy do Marseille, plavbu se zastávkami v Port Saidu, Džibuti a Adenu, pobyt na Srí Lance a cestu napřič Indií. Druhý díl Malajskem na Sumatru začíná přistáním na ostrově Penang a pokračuje ličením cesty Malajským poloostrovem do Singapuru a pobytu na Sumatře. Zastávku v Rangúnu Novák zařadil do třetího dílu $V$ zemi žlutých, spolu s popisem návštěvy Vietnamu a Kambodži, zastávkami v Hong Kongu a Šanghaji a zpáteční cestou přes Koreu, Čínu a Sovětský svaz. Poslední díl Japonské jaro je celý věnován pobytu v Japonsku.

Ve srovnání s dřive vydanými cestopisy o Spojených státech amerických a o Oceánii jsou čtyři díly popisující asijskou cestu mnohem podrobnější. Novák se snažil čtenářům zprostředkovat zážitky z cesty $v$ celé jejich šíri, jak uvádí v úvodu první knihy Cejlonem a Indií: „Snažil jsem se hlavně, abych poznal z vlastní zkušenosti ony daleké tropické kraje a život, zvyky a mravy jejich obyvatelstva a mohl je pravdivě vylíčit ve svých knihách. Dnes cestovati do těch vzdálených zemí je velmi nákladné a obtižné. Každý z nás též nemůže opustiti na delši čas své povolání a věnovati na cesty peniz, který dnes představuje slušný majetek. Pro ně jsou určeny mé knihy. Vynasnažím se, aby čtenár̆ poznal vše, co já jsem viděl a prožil, jako by každý den cestoval se mnou. Nebude ho to ovšem stát těžké desetitisíce a rovněž bude ušetřen všech trampot, obtiži a nebezpeči té daleké cesty. To je pravý účel mých cestopisů a jsem přesvědčen, že je to skvělá protihodnota za peníz, který za ně zaplatíte."10

Líčení vlastní cesty doplnil A. V. Novák ve všech dílech faktografickými kapitolami z literatury, které čtenáře seznamuji s prírodními poměry, dějinami, hospodářstvím, náboženstvím a kulturou popisovaných zemí. Popis vlastní cesty je také doplněn o subjektivní hodnocení a názory autora na různé situace

${ }^{10}$ Novák 1931a, 8-9. 


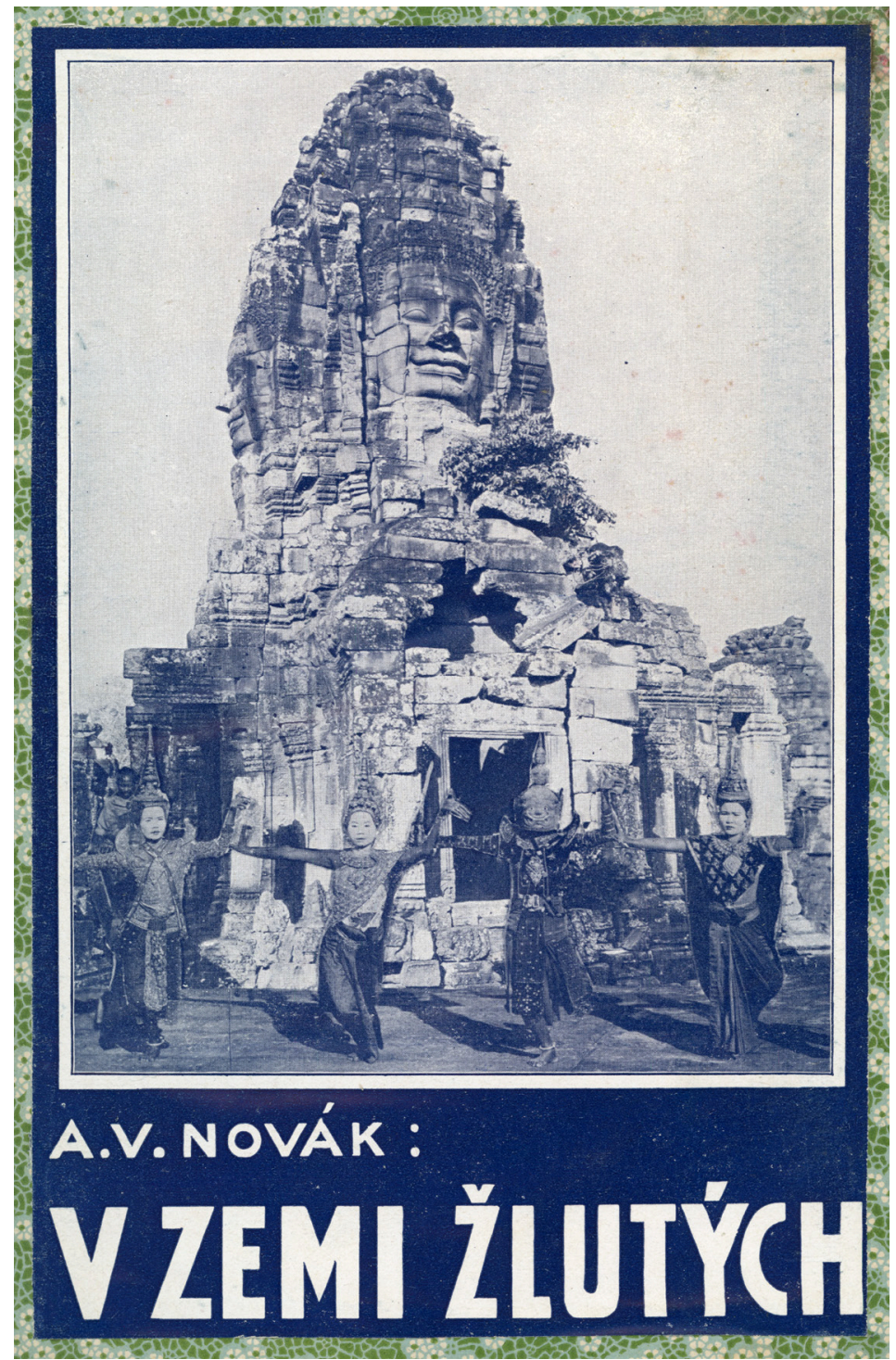

Příloha 5. Obálka brožovaného vydání cestopisu V zemi žlutých. Zdroj: Novák, A. V. 1932. V zemi žlutých. Horní Černošice: Nakladatelství knih cestovatele A. V. Nováka. 
a jevy, se kterými se setkal. Novák hodnotí aktuální politickou situaci, hospodářské podmínky i společenské jevy $v$ jednotlivých zemích. Na otázku koloniální nadvlády $v$ Asii nahliží optikou své doby. Vliv kolonizace vnímá jako prospěšný z hlediska hospodářského a technického rozvoje - rozvoj dopravy a využití přírodního bohatství. Například situaci na Malajském poloostrově hodnotí, že „Každý nepředpojatý pozorovatel musí uznati, že pro hospodářský a technický rozvoj země vykonali zde Angličané za poměrně krátkou dobu velice mnoho. $S$ jejich přichodem teprve začal vzrůst, rozvoj a prosperita celé kolonie. Oni vybudovali skvělé železnice a neméně výbornou hustou sit cest a umožnili také zakládati výnosné plantáže po celém vnitrozemí, takže hospodářsky země ohromně vzrostla. Zato v kulturním rozvoji kolonie se Angličané zastavili v polovině cesty. Vymanili Malajce i vnitrozemni obyvatele z otroctví sultánů, ale třebaže je hospodářsky podporují, nestarají se valně o jejich další vzdělání a duševní rozvoj, a nechávají je tak napospas kulturně vyspělejším Číňanům... Pochybuji, že je to správná politika, nebot při rozumném vedení mohly by $v$ nich míti Angličané proti Čínanům výborné spojence. Prozatím jsou si Angličané $i$ bez nich vědomi své moci a nepotřebují jich - avšak je otázka, zdali si budou tak jisti ještě za nějakých sto let...".11

Cestopisy jsou bohatě doplněny obrazovou přilohou, kterou tvoři jednak méně kvalitní černobílé reprodukce fotografií v textu, jednak kvalitnějši reprodukce na vložených přilohách, vytištěné na křídovém papíre. První díl Celjonem a Indií osahuje 94 vyobrazení v textu a 12 na prílohách, druhý díl Malajskem na Sumatru 98 ilustrací v textu a 12 na prílohách, třetí díl $V$ zemi žlutých 90 ilustraci v textu a 10 a přilohách a čtvrtý díl Japonské jaro 122 ilustrací v textu a 11 na přilohách. Autorství snímků Novák většinou neuvádí. Je jisté, že vlastní snímky doplňoval koupenými fotografiemi a pohlednicemi.

${ }^{11}$ Novák 1931b, 112. 
Srovnáním s dochovanými diapozitivy se ukázalo, že v řadě připadů použil Novák stejný snímek pro přednášku i pro cestopis. Při srovnání dochovaných přednášek s cestopisy navíc najdeme podobné tematické členění. Texty přednášek se sice nedochovaly, ale na diapozitivech najdeme pořadová čísla a původní popisky, které zpravidla tvoří začátek věty z textu $v$ místě, kdy se měl diapozitiv vyměnit. Dohledání stejného snímku $v$ cestopise tak v řadě prípadů pomohlo konkrétní výjev lépe určit, případně z príslušné části textu získat další kontext.

A. V. Novák čerpal ze své asijské cesty také bohatou inspiraci pro populární beletrii. První knihou, inspirovanou touto cestou, byl román Když kvetly sakury, vydaný již v roce 1927. Text je datován Kobe, $v$ dubnu $1927,{ }^{12}$ což svědčí o tom, že Novák jej napsal přímo při pobytu v Japonsku. Celkem A. V. Novák vydal pět románů a deset povídkových sbírek, inspirovaných asijskou cestou. Knihy inspirované stejnou oblastí přitom často vycházely ve stejném roce, což svědčí o tom, že autor systematicky zpracovával získaný materiál.

Návštěva Srí Lanky a Indie byla zdrojem inspirace k románu Tajemná Indie (1930) a povídkových sbírek Indické povídky (1930) a Povídky z Cejlonu (1930). Do oblasti Malajského poloostrova je zasazen román Svody tropů (1928) a povídková sbírka Nani Sutra a jiné povídky z Malajska (1928). Na ostrov Sumatru je situován děj povídek ze sbírky Dobrodružství na Sumatře (1928). Prostředí dnešního Vietnamu a Kambodži využil v románu Láska na palubě Amazonky (1929) a v povídkové sbírce Dívky z Annamu (1929). Do prostředí Číny jsou situovány povídky ze sbírky $V$ Šanghaji za revoluce (1929) a částečně také děj románu Cesta čtyř (1938), který se odehrává z větší části na palubě vlaku Transsibiřské magistrály. Nejvíce A. V. Novák ve svých románech a povídkách čerpal z pobytu $v$ Japonsku, kam jsou

${ }^{12}$ Novák 1927a, 5. 


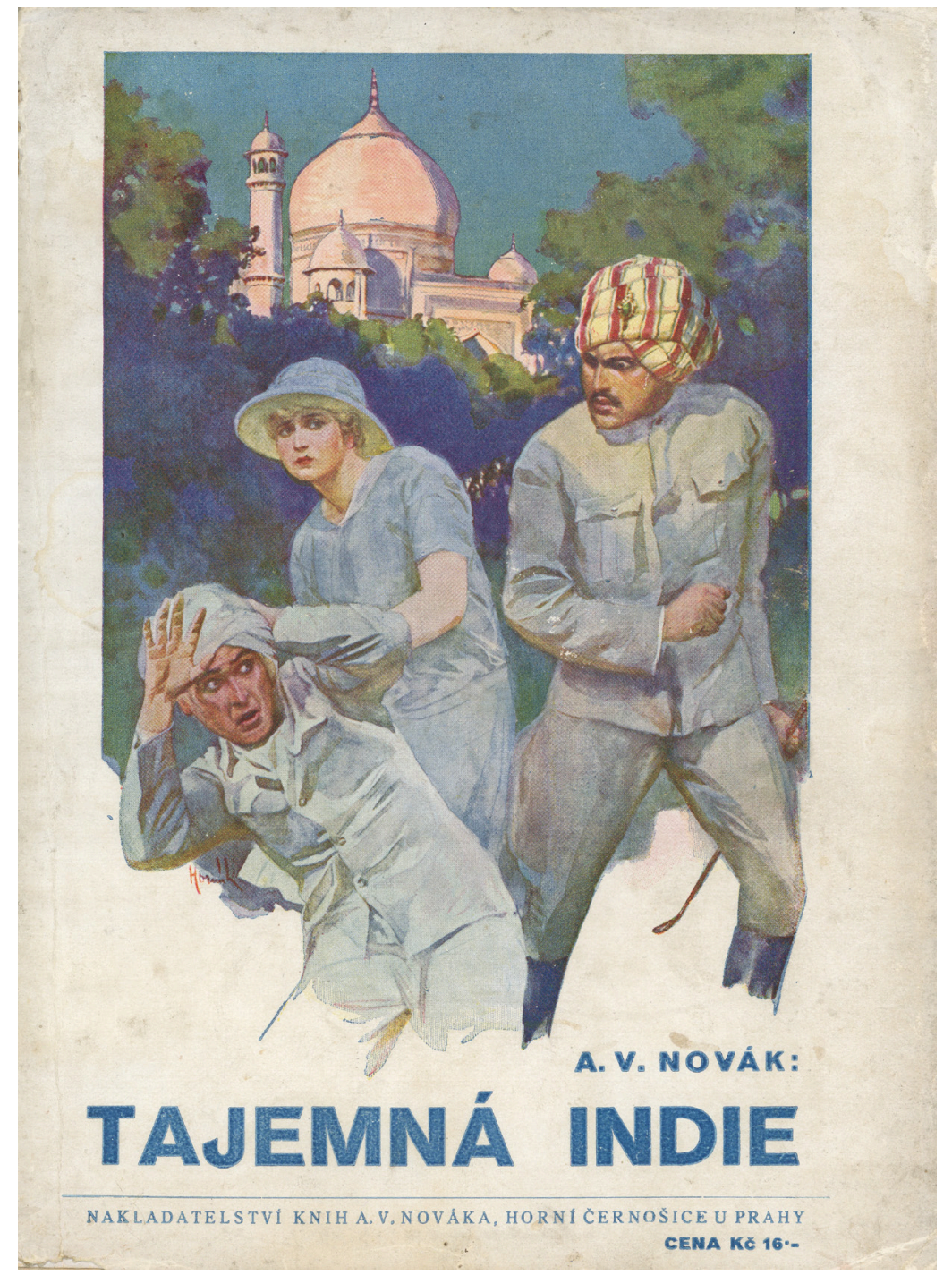

Přiloha 6. Obálka brožovaného vydání románu Tajemná Indie s ilustrací Františka Horníka. Zdroj: Novák, A. V. 1930. Tajemná Indie. Horní Černošice: Nakladatelství knih cestovatele A. V. Nováka. 

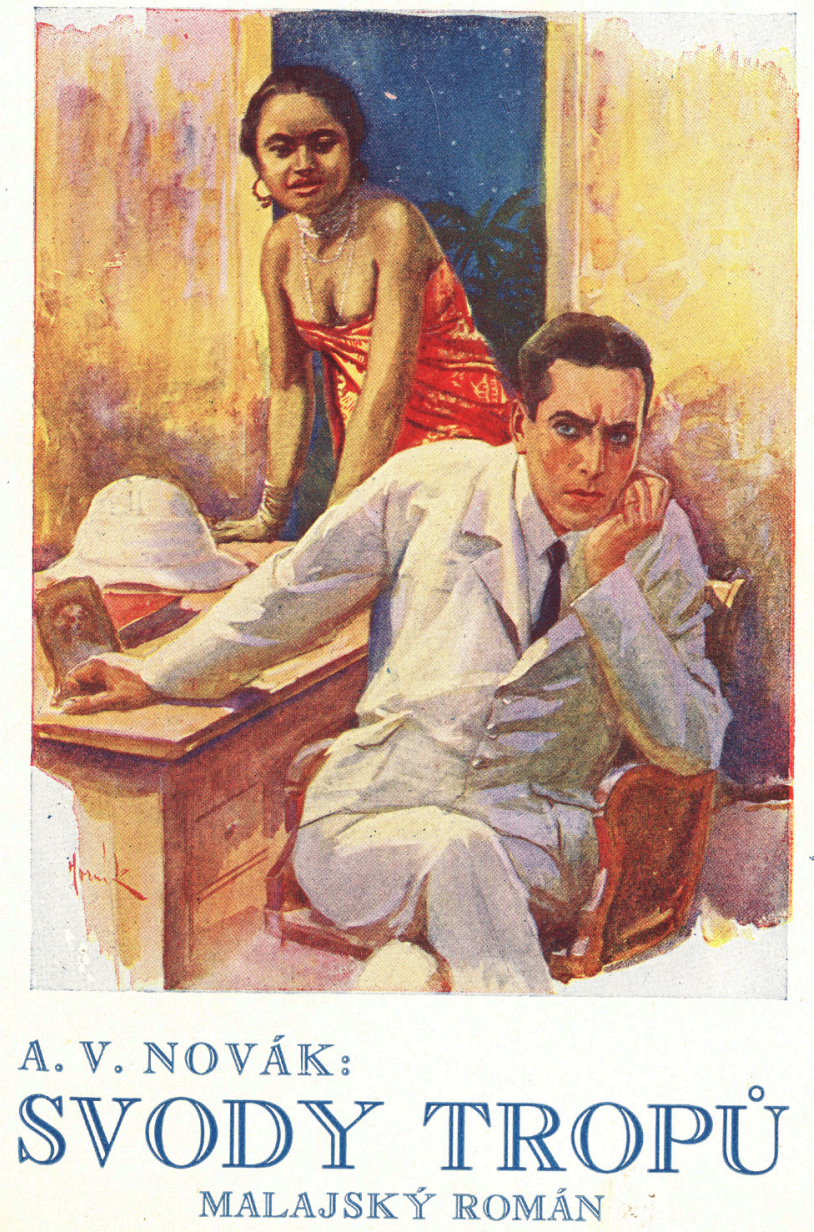

NAKLADATELSTVI KNIH A. V. NOVA KA, HORNI ČERNOSICE U PRAHY

Příloha 7. Obálka brožovaného vydání románu Svody tropů s ilustrací Františka Horníka Zdroj: Novák, A. V. 1928. Svody tropů. Horní Černošice: Nakladatelství knih cestovatele A. V. Nováka. 
kromě již zmíněného románu Když kvetly sakury zasazeny také povídkové sbírky Povídky o gejšách (1927), Japonské ženušky (1927), Japonské lásky (1935) a Úsměvy Nipponu (1935).

Novákovy romány a povídky mívají podobné schéma. Děj je zasazený do reálii dané země, převládají milostné zápletky. U povídek je děj jednodušší, většinou s jednou, nejčastěji milostnou zápletkou. Nejčastěji se jedná o vztah Evropana a domorodé dívky, v menší míre se objevují i príběhy o vztazích Evropanek s místními muži. Výjimkou nejsou ani milostné trojúhelníky. Dalším typem povídek jsou príběhy místních obyvatel, které ukazuji nějaký tradiční fenomén spojený s danou oblastí a kulturou.

Vyznění přiběhu bývá bud' dramatické, často s tragickým koncem, satirické s humornými scénami či poučné, kdy postava prochází určitými zkušenostmi, jejichž prostřednictvím mění svůj pohled na svět. Občas se objevují i detektivní a záhadné prvky. $V$ románech jsou príběhy složitější, často se $v$ jejich průběhu odehraje určitý úsek cesty. Popis reálií často přímo vychází z Novákovy vlastní zkušenosti. V úvodu svých knih A. V. Novák často uvádí podrobnosti o tom, jak konkrétní dílo vznikalo, prípadně co jej inspirovalo. Podle uvedené datace psal Novák některá díla přímo na své cestě.

Novákovo nakladatelství nuceně ukončilo svou činnost po komunistickém převratu v roce 1948. Sám A. V. Novák, který se ve třicátých letech věnoval vedle svých literárních aktivit také komunální politice, byl zcela vyloučen z veřejného života. Přes veškerou snahu se znovu uplatnit se již neprosadil, navíc se potýkal s finančními i zdravotními problémy. Změny poměrů se již nedožil, zemřel 8. srpna 1979 v nemocnici v Třebotově. S jeho knihami se dnes nejčastěji setkáme v nabídce antikvariátů, ve fondech veřejných knihoven jsou zastoupeny o poznání méně. 
Novákovo svébytné dílo má pritom i dnes co nabídnout. Kromě informací o pozoruhodných osudech i názorech svého autora můžeme jeho prostřednictvím lépe poznat čtenářský vkus české populace 20. a 30. let i dobový pohled na svět. Novákovy detailní popisy prostředí, spolu s dochovanou fotografickou pozůstalostí, jsou také zajímavým zdrojem informací o mimoevropských zemích. A. V. Novák si často všímal a zaznamenal věci, které jiní cestovatelé opomijeli. Např́iklad jeho popis nabídky zboži na tržišti na Sumatře se ukázal jako cenný zdroj při etnografickém výzkumu indonéské sbírky Náprstkova muzea. ${ }^{13}$ Výchozím bodem pro dalši bádání může být monografie vydaná autorem tohoto príspěvku v roce 2020, která shrnuje výsledky několikaletého výzkumu a dává přehled o Novákově životě, díle, i dochované fotografické a archivní pozůstalosti. ${ }^{14}$

\section{Literatura}

Česká televize. 2004. „Příběhy z jižních moří.“ 14. 5. 2021. https:// www.ceskatelevize.cz/porady/1130993618-pribehy-z-jiznich-mori

Hubinger, Martin a Jan Šejbl. 2012. Temptations of the tropics. A photographic archive to Malaya by A. V. Novák. Kuala Lumpur: Velvyslanectví České republiky v Kuala Lumpuru a Národní muzeum.

Janáček, Pavel. 2004. Literární brak. Operace vyloučení, operace nahrazení 1938-1951. Brno: Host.

Kerlogue, Fiona a Dagmar Pospíšilová. 2018. Collecting Experience in the 1930s. Indonesian and Pacific collections of Růžena Charlotta Urbanová in the National Museum. Praha: Národní muzeum.

\footnotetext{
${ }^{13}$ Kerlogue a Pospíšilová 2018, 84.

${ }^{14}$ Šejbl 2020.
} 
Křestan, Jiři. 2000. „Osudy české kolonie na Tahiti (1924-1938).“

Paginae historiae: sborník Státního ústředního archivu v Praze, č. 8. Praha: Státní ústřední archiv v Praze, 123-153.

Novák, A. V. 1925. Tropické noci. Horní Černošice: Nakladatelství knih cestovatele A. V. Nováka.

Novák, A. V. 1927. Když kvetly sakury. Horní Černošice: Nakladatelství knih cestovatele A. V. Nováka.

Novák, A. V. 1927. Japonské ženušky. Horní Černošice: Nakladatelství knih cestovatele A. V. Nováka.

Novák, A. V. 1929. Láska na palubě Amazonky. Horní Černošice:

Nakladatelství knih cestovatele A. V. Nováka.

Novák, A. V. 1927. Povídky o gejšách. Horní Černošice: Nakladatelství knih cestovatele A. V. Nováka.

Novák, A. V. 1928. Dobrodružství na Sumatře. Horní Černošice: Nakladatelství knih cestovatele A. V. Nováka.

Novák, A. V. 1928. Nani Sutra a jiné povídky z Malajska. Horní Černošice: Nakladatelství knih cestovatele A. V. Nováka.

Novák, A. V. 1928. Svody tropů. Horní Černošice: Nakladatelství knih cestovatele A. V. Nováka.

Novák, A. V. 1929. Dívky z Annamu. Horní Černošice: Nakladatelství knih cestovatele A. V. Nováka.

Novák, A. V. 1929. V Šanghaji za revoluce. Horní Černošice: Nakladatelství knih cestovatele A. V. Nováka.

Novák, A. V. 1930. Indické povídky. Horní Černošice: Nakladatelství knih cestovatele A. V. Nováka.

Novák, A. V. 1930. Povídky z Ceylonu. Horní Černošice: Nakladatelství knih cestovatele A. V. Nováka.

Novák, A. V. 1930. Tajemná Indie. Horní Černošice: Nakladatelství knih cestovatele A. V. Nováka.

Novák, A. V. 1931. Cejlonem a Indií. Horní Černošice: Nakladatelství knih cestovatele A. V. Nováka.

Novák, A. V. 1931. Malajskem na Sumatru. Horní Černošice: Nakladatelství knih cestovatele A. V. Nováka. 
Novák, A. V. 1931. Tahiti, rajské ostrovy jižních moři. 2. vydání. Horní Černošice: Nakladatelství knih cestovatele A. V. Nováka. Novák, A. V. 1932. Japonské jaro. Horní Černošice: Nakladatelství knih cestovatele A. V. Nováka.

Novák, A. V. 1932. V zemi žlutých. Horní Černošice: Nakladatelství knih cestovatele A. V. Nováka.

Novák, A. V. 1933. Cesta mládí I. V okovech. Horní Černošice: Nakladatelství knih cestovatele A. V. Nováka.

Novák, A. V. 1935. Japonské lásky. Horní Černošice: Nakladatelství knih cestovatele A. V. Nováka.

Novák, A. V. 1935. Úsměvy Nipponu. Horní Černošice: Nakladatelství knih cestovatele A. V. Nováka.

Novák, A. V. 1938. Cesta čtyř. Horní Černošice: Nakladatelství knih cestovatele A. V. Nováka.

Šejbl, Jan. 2020. Hříšná exotika. Archibald Václav Novák. Praha: Národní muzeum.

Ustohal, Vladimír. 2005. Češi na Tahiti a Markézách. Brno: CERM. 